past year. In four cases bone-marrow suppression was limited to the myeloid compartment, ${ }^{1-4}$ whereas in the present case, as in the one reported by Gavras et $a l,{ }^{5}$ the erythroid and megakaryocytic cell lines were all suppressed. In four cases, as in ours, the patients had renal insufficiency. Since captopril is eliminated by the kidney, toxic concentrations of the drug may have developed. Other drugs were given in three cases, including immunosuppressives in one, and one patient was suspected of having underlying blood dyscrasia, ${ }^{4}$ but our patient had no underlying disease and the combined antihypertensive drugs are not known to cause haematological toxicity.

This report emphasises that caution should be used in all patients with renal failure and that frequent blood counts should be made in such patients during treatment with captopril.

${ }^{1}$ Amann FW, Bühler FR, Conen D, Brunner F, Ritz R, Speck B. Captoprilassociated agranulocytosis. Lancet $1980 ; \mathrm{i}: 150$.

2 Van Brummelen P, Willemze R, Tan WD, Thompson J. Captoprilassociated agranulocytosis. Lancet $1980 ; \mathrm{i}: 150$.

${ }^{3}$ Elijovisch F, Krakoff LR. Captopril associated granulocytopenia in hypertension after renal transplantation. Lancet 1980 ;i:927-8.

4 Staessen J, Fagard R, Lijnen P, Amery A. Captopril and agranulocytosis. Lancet 1980 ; $:$ :926-7.

5 Gavras I, Graff LG, Rose BD, McKenna JM, Brunner HR, Gavras H. Fatal pancytopenia associated with the use of captopril. Ann Intern Med $1981 ; 94: 58-9$.

(Accepted 6 May 1981)

Department of Internal Medicine, Hôpital Charles Nicolle, Tunis, Tunisia

A EL MATRI, MD, professeur agrégé in intensive care

M S LARABI, MD, resident in intensive care and dialysis unit

$C$ KECHRID, MD, resident in intensive care and dialysis unit

C BELKAHIA, MD, professeur agrégé in pharmacology, faculty of medicine $\mathrm{H}$ BEN AYED, $M D$, professor and chief of department of internal medicine

\section{Effect of sulphonylurea on insulin secretion and glucose control in insulin-treated diabetics}

Endogenous insulin secretion in insulin-dependent diabetics has an important role in assisting blood glucose control. ${ }^{12}$ Stimulation of endogenous insulin secretion by treatment with a sulphonylurea might therefore be advantageous. We carried out a cross-over trial of glibenclamide and placebo in patients with diabetes of recent onset, who might be expected to have some endogenous insulin secretion, to determine whether the sulphonylurea increased the insulin secretion or improved diabetic control.

\section{Patients, methods, and results}

Eight diabetic men volunteered for the study. One was withdrawn because of a hypoglycaemic reaction to the active treatment, but his previous 24 -hour plasma glucose profile, during placebo treatment, had shown a glucose concentration of $1-2 \mathrm{mmol} / 1(18 \cdot 0-36 \cdot 0 \mathrm{mg} / 100 \mathrm{ml})$ on several occasions. The seven other patients received a constant insulin dose throughout the study and were analysed together. All were aged 20-47 and had had diabetes for a mean of 3.5 years (range $0.5-8$ years).

Six patients were treated with Ultratard insulin as a basal supplement, four with additional twice-daily Actrapid insulin to cover meals and two with Actrapid and Semitard in the morning and Actrapid and Ultratard in the evening. ${ }^{3}$ One patient was treated with Actrapid and Retard twice daily. The mean dose was $0.7 \mathrm{U} / \mathrm{kg}$ (range $0.31-1.0 \mathrm{U} / \mathrm{kg}$ ). The patients were treated double blind with glibenclamide $10 \mathrm{mg}$ twice daily or placebo tablets for four weeks and then admitted at 1730 for a 24 -hour profile, blood samples being taken via a forearm intravenous Teflon cannula. They were given normal food and insulin treatment, were up and dressed, but took less exercise than usual. Blood glucose was measured by the glucose oxidase method (Boehringer GOD-perid).

C-peptide, secreted in equimolar amounts with insulin, provides a means of monitoring endogenous insulin secretion in insulin-treated patients. Plasma C-peptide concentration was measured by immunoassay using antiserum and ${ }^{125}$ I-labelled C-peptide and charcoal phase separation (precision $\pm 0.02( \pm 1 \mathrm{SD}) \mathrm{nmol} / \mathrm{l})$. The antibody-bound proinsulin was separated by polyethylene glycol precipitation. ${ }^{4}$ The mean normal fasting plasma C-peptide concentration was $0.35 \mathrm{nmol} / 1(105 \mathrm{mg} / 100 \mathrm{ml})$ (range $0.1-0.5 \mathrm{nmol} / 1$ ( $0.3-$ $1.5 \mathrm{mg} / 100 \mathrm{ml})$ ), rising to a mean peak of $1.2 \mathrm{nmol} / 1(3.6 \mathrm{mg} / 100 \mathrm{ml})$ one hour after meals. Haemoglobin $A_{1 c}$ was assessed by isoelectric focusing, the normal range being $5 \cdot 8-8 \cdot 0 \%$ total haemoglobin. Statistical tests included the paired $t$ test.

Four patients had immunoreactive C-peptide while taking the placebo; none of the three others developed immunoassayable C-peptide when taking glibenclamide. The plasma $\mathrm{C}$-peptide concentration in these four patients did not increase substantially with treatment (mean $( \pm \mathrm{SD})$ 24 -hour concentration $0 \cdot 14 \pm 0.08 \mathrm{nmol} / 1$ with placebo $v 0 \cdot 21 \pm 0 \cdot 12 \mathrm{nmol} / 1$ with treatment $(0.4 \pm 0.2 v 0.6 \pm 0.3 \mathrm{mg} / 100 \mathrm{ml}))$. Blood glucose control, as measured by 24 -hour profiles (figure), did not improve in either the four patients with C-peptide (mean 24-hour fasting plasma glucose concentration $7.7 v 7.4 \mathrm{mmol} / 1(138.7 v 133.3 \mathrm{mg} / 100 \mathrm{ml}))$ or the three patients without C-peptide (mean $10.9 v 12.5 \mathrm{mmol} / 1(32.7 v 37.5 \mathrm{mg} / 100 \mathrm{ml})$ ). Haemoglobin $\mathrm{A}_{1 \mathrm{c}}$ showed little difference (mean $\left.10.8 v 9.5 \%\right)$ except in one patient $(9.6 v$ $5.9 \%$ ), who received the least insulin ( $20 \mathrm{U}$ Ultratard/day alone) and had the highest mean 24-hour plasma C-peptide concentration, which increased from 0.25 to $0.39 \mathrm{nmol} / 1(0.7$ to $1.1 \mathrm{mg} / 100 \mathrm{ml})$ with glibenclamide treatment.

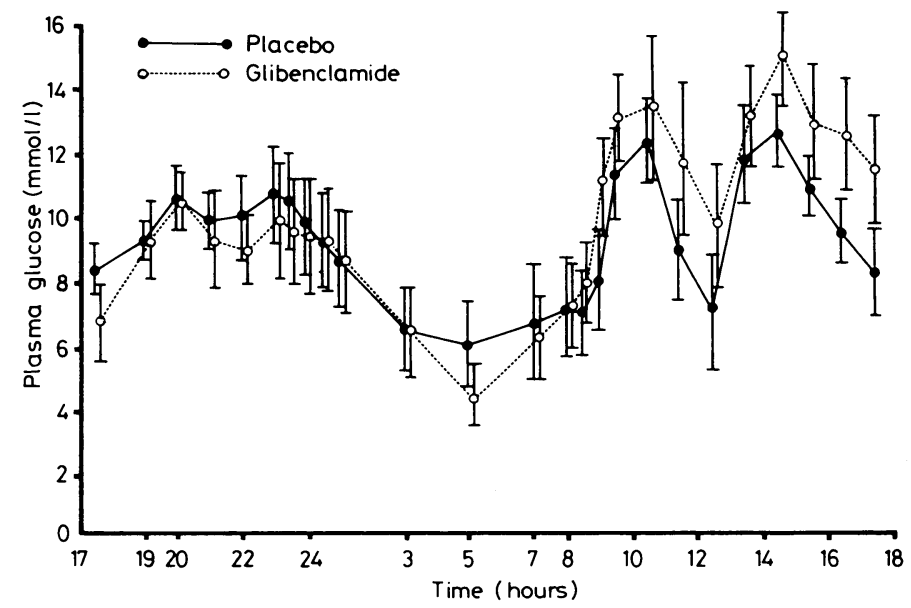

Mean ( \pm 1 SD) 24-hour plasma glucose concentrations in seven insulintreated diabetics taking placebo and glibenclamide $20 \mathrm{mg} /$ day.

Conversion: SI to traditional units-Plasma glucose: $1 \mathrm{mmol} / 1 \approx 18 \mathrm{mg} / 100$ $\mathrm{ml}$

\section{Comment}

This study suggests that most insulin-treated patients would receive little benefit from stimulation of endogenous insulin secretion with a sulphonylurea. Patients with diabetes of recent onset with considerable beta-cell secretion might benefit but already have fairly good diabetes control. ${ }^{1}$ Patients with little or no endogenous insulin secretion and poor diabetes control do not appear to be improved by treatment with a sulphonylurea. Any affect of sulphonylurea on insulin receptors ${ }^{5}$ is unlikely to help control in insulin-dependent diabetics, in whom poor control is due mainly to lack of physiological meal-related insulin responses rather than the degree of overall insulin sensitivity.

We thank Novo Research Industri and Hoechst AG for grants, Dr Lise Heding for providing the ${ }^{125} \mathrm{I}$-labelled C-peptide, and Mrs M Burnett and Mrs J Morris for technical help.

Ludvigson J, Heding LG, Larsson Y, Peander E. C-peptide in juvenile diabetics beyond the post-initial remission period. Relation to clinical manifestations at onset of diabetes, remission and diabetic control. Acta Paediatr Scand 1977;66:177-84.

2 Yue OK, Baxter RC, Turtle JR. C-peptide secretion and insulin antibodies as determinants of stability in diabetes mellitus. Metabolism 1978;27: 35-44.

${ }^{3}$ Phillips M, Simpson RW, Holman RR, Turner RC. A simple and rational twice daily insulin regime. $Q \mathcal{F}$ Med 1979;191:493-506.

4 Kuzuya H, Blix PM, Horwitz DL, Steiner DF, Rubenstein AH. Determination of free and total insulin and C-peptide in insulin treated diabetics. Diabetes $1977 ; \mathbf{2 6}: 22-9$.

${ }^{5}$ Prince MJ, Olefsky JM. Direct in vitro effect of a sulphonylurea to increased human fibroblast insulin receptors. F Clin Invest 1980;66:608-11.

(Accepted 6 May 1981)

Diabetes Research Laboratories, Nuffield Department of Clinical Medicine, Radcliffe Infirmary, Oxford OX2 6HE

E A WARD, MB, research fellow

G M WARD, FRACP, research fellow

R C TURNER, FRCP, clinical reader . D. .

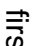

